\title{
Features of Inorganic Carbon Regional Balance in Marine Ecosystems under Anthropogenic Pressure
}

\author{
N. A. Orekhova*, S. K. Konovalov, E. V. Medvedev \\ Marine Hydrophysical Institute of RAS, Sevastopol, Russian Federation \\ * natalia.orekhova@mhi-ras.ru
}

\begin{abstract}
Purpose. Global changes in the ocean biogeochemical structure are mostly pronounced on a regional scale. They are caused by the increased carbon flux to the aquatic ecosystems that is a result of its growing emission from the atmosphere, coastal sinks as well as and the primary production and degradation processes taking place in marine environments. It seems reasonable to separate the enumerated sources to the natural climatic factors and the anthropogenic ones which are considered in the studies of a carbon cycle. To assess the quantitative characteristics of the factor leading to natural carbon cycle transformation, it is necessary to reconstruct its budget, which is governed by the carbon intake and removal, as well as by the processes resulting in its redistribution between various forms. Methods and Results. The carbon budget in the Sevastopol Bay ecosystem (the Black Sea) is assessed, and contribution of the anthropogenic component is analyzed based on the long-term research (2007-2018) of hydrochemical and geochemical characteristics. The following results of the sediment carbonate system studies, namely the vertical profile of dissolved inorganic carbon (DIC), total alkalinity (TA) and $\mathrm{pH}$, and the dissolved inorganic carbon and alkalinity ratio show that the organic matter oxidation occurs mainly under the anaerobic conditions. It has been also revealed that the dissolved inorganic carbon flux $\left(J_{\mathrm{DIC}}\right)$ at the "water - sediment" boundary is directed from sediments to the bottom waters and amounts $0.42-0.61 \mathrm{~mol} \cdot \mathrm{m}^{-2} \cdot \mathrm{year}^{-1}$.

Conclusions. Different components of the inorganic carbon budget showed that the anthropogenic sources were the most important: their contribution constituted not less than $75 \%$ of the total inorganic carbon inflow. Based on the value of the dissolved inorganic carbon total reserve and its removal to the open sea, the time of complete renewal of the Sevastopol Bay waters is assumed to be 2 years and 4 months.
\end{abstract}

Keywords: carbon budget, dissolved inorganic carbon, DIC flux, carbonate system, Sevastopol Bay, Black Sea.

Acknowledgements: the authors are thankful to the colleagues of the Marine Biogeochemistry Department, FSBSI MHI, for their assistance in expeditionary and analytical studies. The investigation is carried out within the framework of theme No. 0827-2018-0004, the RFBR projects No. 16-35-60006 mol_a dk "Long-term changes of the carbon cycle characteristics in the Sevastopol Bay" and No. 18-05-80028 Hazardous phenomena "Studies and scaling of water dynamics and biogeochemical processes in development of oxygen deficit and sulfidic conditions in coastal regions of Crimea and Kerch Strait".

For citation: Orekhova, N.A., Konovalov, S.K. and Medvedev, E.V., 2019. Features of Inorganic Carbon Regional Balance in Marine Ecosystems under Anthropogenic Pressure. Physical Oceanography, [e-journal] 26(3), pp. 225-235. doi:10.22449/1573-160X-2019-3-225-235

DOI: $10.22449 / 1573-160 X-2019-3-225-235$

(C) 2019, N. A. Orekhova, S. K. Konovalov, E. V. Medvedev

(C) 2019, Physical Oceanography

At present, the fact of global changes in the World Ocean biogeochemical structure is undoubted. In a great extent it concerns regional changes. In particular, a decrease in the oxygen concentration and the appearance of oxygen deficiency zones, nutrients increase, as well as a $\mathrm{pH}$ shift towards acidic conditions in the open ocean, at the shelf and in the coastal areas were noted [1-4]. These changes are predominantly due to eutrophication, i. e. an increase in carbon flux into aquatic ecosystems as a result of an increase in its release from the atmosphere, PHYSICAL OCEANOGRAPHY VOL. 26 ISS. 3 (2019) 
coastal sources, and also due to primary production and destruction processes in the marine environment. Most researchers believe that the carbon dioxide concentration increase in the atmosphere is caused by climatic and anthropogenic influence. Eutrophication of ecosystems is mainly associated with the nutrients and organic matter input with river discharge and municipal wastewaters to coastal ecosystems, as well as the development of agriculture and animal husbandry. As a result of all these processes, the natural cycles of the main elements, primarily the carbon cycle, are transformed. However, it is still an open question about the separation of climatic and anthropogenic factors effect on the carbon cycle.

Coastal ecosystems are most susceptible to human impact. Despite the significantly smaller volume of coastal and shelf waters (in comparison with the World Ocean water volume), any changes occurring in them are characterized by a faster and more pronounced response. Although coastal ecosystems occupy a little more than $7 \%$ of the World Ocean total area and less than $0.5 \%$ of its volume, their contribution to biogeochemical processes involving carbon is disproportionately large [5].

It was determined that the World Ocean shelf ecosystems absorb $\sim 0.25-0.36 \mathrm{PgC} \cdot$ year $^{-1}$ from the atmosphere, which is equivalent to $\sim 16-23 \%$ of the total carbon dioxide absorbed by the ocean [6]. River runoff - the main source of terrigenous organic matter and nutrients, - household and industrial wastewaters get into the coastal zone. Prolonged changes in estuaries manifest themselves in a change in carbon flux [7]. It is the coastal zone where the most part of organic carbon is produced and oxidized, which significantly affects the oxygen budget, redox and acid-base characteristics of the coastal ecosystem. Changes in the ecosystem physical characteristics, such as river runoff volume and sea level, also affect the biogeochemical processes occurring in estuaries, and, as a result, the exchange processes of $\mathrm{CO}_{2}$ and DIC at the interface boundary, including the atmosphere.

In order to quantify and share the factors leading to the transformation of the natural carbon cycle, it is necessary to reconstruct its budget. In this case, knowing the source and intensity of the anthropogenic impact, we can try to assess the degree of its effect.

The carbon budget in marine ecosystems is determined by both the carbon input and removal and the processes that result in its redistribution between various forms (organic and inorganic components). It is most convenient to carry out a quantitative reconstruction of the budget and its analysis for closed and semienclosed coastal ecosystems, for which the estimates of physical, physicalchemical and biogeochemical carbon fluxes within the system and at its boundaries can be obtained.

In this work, the assessment of the carbon budget for the Sevastopol Bay ecosystem (the Black Sea), as well as an analysis of the anthropogenic component contribution, were performed.

\section{Materials and methods}

The Sevastopol Bay is a semi-enclosed water area with limited water exchange. The Chernaya River is the only permanent stream that discharges its waters in the top of the bay (Fig. 1). This is manifested in the desalination of the 
bay surface waters, a significant intake of mineral and organic matters, including nutrients and dissolved forms of inorganic carbon, especially during the flood period $[8,9]$. According to its characteristics, the Sevastopol Bay ecosystem can be attributed to an estuarine type (with the exception of tidal fluctuations) $[10,11]$. The objects of urban and industrial infrastructure, as well as maritime transport, are situated on its shores, which increases the load on the bay ecosystem.

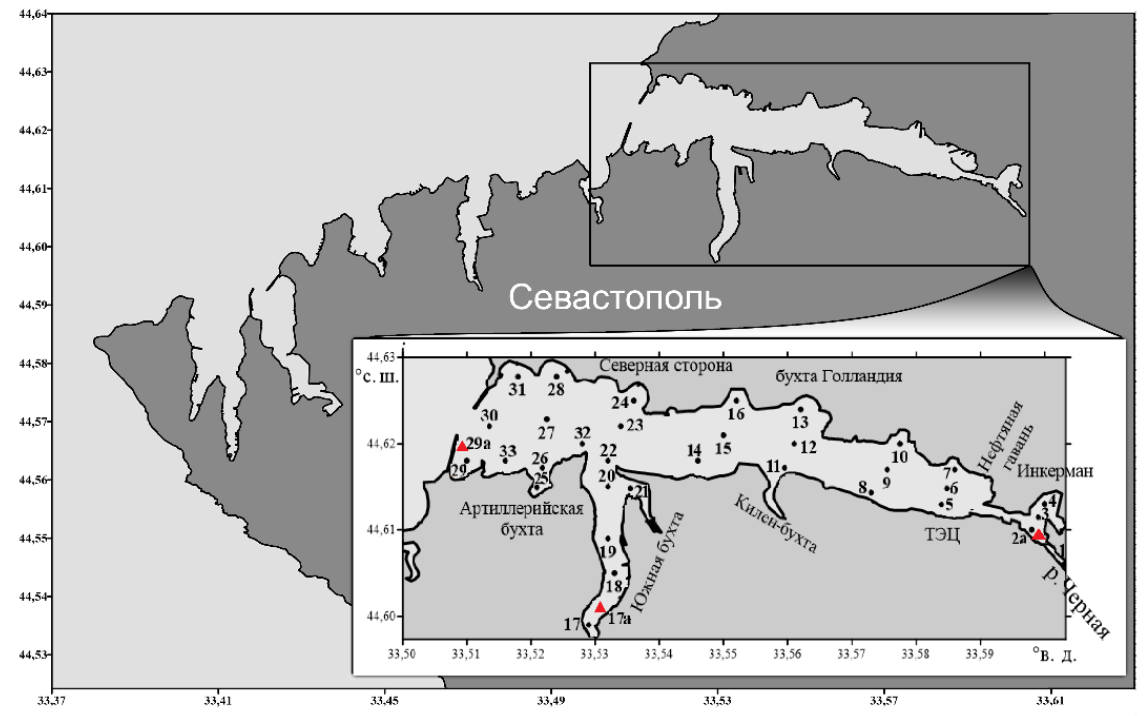

F i g. 1. Scheme of the sampling stations in the Sevastopol Bay

The data obtained from monitoring observations of the Sevastopol Bay from 2007 to 2018 were used in the work. During the research, water samples were taken with a Niskin bottles from the surface and bottom along the grid of stations (Fig. 1). In addition, in May 2018, sediment columns were sampled in the Sevastopol Bay, analysis of which allowed us to obtain a vertical profile of the carbonate system components - total alkalinity (TA) and $\mathrm{pH},-$ and also to determine DIC from direct measurements. Bottom sediments were collected by a diver in a plexiglas tubes. At the same time, in the samples, conditions were kept maximal close to natural: the presence of a bottom waters above the sediment, an undisturbed surface and the structure of bottom sediments. This provides a study of processes at the interface boundary with bottom waters, including giving numerical estimates of carbon dioxide flux and total dissolved inorganic carbon.

For all hydrochemical analyzes standard methods were used [12].

Total alkalinity (TA) was determined by direct titration with a potentiometric ending, $\mathrm{pH}$ - potentiometrically in an open cell using buffer solutions of NBS scale. The calculation was carried out taking into account the temperature correction [12]. DIC, $\mathrm{CO}_{2}, \mathrm{pCO}_{2}$ values for the seawater were calculated from measured $\mathrm{pH}$ and TA values $[13,14]$ using carbonic acid constants recommended by UNESCO Division of Marine Sciences [15]. It was assumed that boron is a conservative element and its content is proportional to salinity. Therefore, the borate component of total alkalinity was calculated from salinity [16]. The effect of the dissociation of water, phosphoric, 
sulfuric, hydrofluoric and other acids contained in low concentrations in the seawater on the alkalinity value was not taken into account. Methods for calculating the carbonate system components are described in detail in $[12,15]$.

Determination of dissolved inorganic carbon (DIC) was carried out using AS-C3 instrument complex based on an LI-7000 DP infrared analyzer. A calibration solution for the instrument complex was the one of sodium carbonate in bidistilled water, which was freed from carbon dioxide by boiling. The concentration of sodium carbonate corresponded to DIC concentration equal to $4000 \mu \mathrm{mol} / \mathrm{dm}^{3}$. Reproducibility in measuring DIC reached $0.1 \%[17,18]$.

The separation of pore waters was performed by centrifugation (centrifugation speed and time were $4000 \mathrm{rpm}$ and $30 \mathrm{~min}$, respectively, sample volume $-85 \mathrm{ml}$ ). In the pore waters, DIC, TA, and $\mathrm{pH}$ were determined according to the methods described above.

In order to calculate the carbon fluxes at the interface boundaries, we used the data obtained in the spring survey of 2018, performed according to the standard station scheme (Fig. 1). Taking into account the fact that bottom sediments are a fairly conservative system, in this paper we consider the total dissolved inorganic carbon flux to be constant.

To calculate the remaining characteristics, we took the averaged data from multi-year research (2007-2018).

\section{Results and their discussion}

The increased intake of nutrients and a rise of the organic matter content in the Sevastopol Bay over the past 20 years has led to a decrease in oxygen concentration due to its consumption by organisms for respiration and organic matter oxidation, as well as to an increase in the concentration of hydrogen ions and $\mathrm{pH}$ shift towards a more "acidic" conditions (the so-called acidification) [19]. River runoff enriched with labile organic matter, domestic and industrial wastewaters increase the acidification of the bay waters, since microbiological oxidation of ammonium and organic matter from wastewater leads to the formation of hydrogen ions, lower $\mathrm{pH}$, an increase in the equilibrium partial pressure of carbon dioxide and $\mathrm{CO}_{2}$ release.

The results of the analysis of bottom sediment columns showed that the maximum DIC concentrations in the pore waters of bottom sediments are characteristic of the Chernaya River mouth area (st. 2a) (Fig. 1, 2), while the organic carbon content is $4.33 \%$ dry weight (in $0-10 \mathrm{~cm}$ layer). High DIC values can be explained by the Chernaya River runoff effect, which is a source of $\mathrm{HCO}_{3}^{-}$ and easily oxidizable organic matter. This is quite expected for the given research area: in estuarine ecosystems with an insignificant tidal force, most of the suspended matter brought in is deposited in the estuary [11], which is reflected in the characteristics of bottom sediments.

It is known [20] that DIC vertical distribution in the water column is significantly affected by primary production and biogeochemical destruction processes. The production of phytoplankton in the surface water layer leads to the $\mathrm{CO}_{2}$ removal from the surface water layer and a decrease in DIC. As the phytoplankton dies off and is deposited in the water column, the suspended organic 
matter is mineralized, and carbon shifts to the dissolved inorganic form. Thus, there is an increase in DIC concentration with depth. DIC content in the water column is determined, in addition to biogeochemical and metabolic processes at the interface boundary, in particular, at the boundary of atmosphere and bottom sediments, as well as water exchange processes with the adjacent water areas. The absorption of anthropogenic $\mathrm{CO}_{2}$ from the atmosphere, due to its physical transport across the interphase boundary, does not affect the total alkalinity (TA) in the water column, determined by the presence of carbonic acid salts, and not by its free form [14]. For the same cause, TA value is insensitive to the biogeochemical processes of organic matter production/destruction. TA slightly varies as a result of microbiological oxidation of organic matter under aerobic conditions, primarily under effect of the oxidation processes of nitrogen reconstructed forms [20]. TA is mostly determined by the change in the concentration of carbonic acid salts, associated with the dissolution or production of calcium carbonate and the transport of dissolved carbonates and bicarbonates. Thus, in the marine ecosystems a change in the concentration of carbonates associated with phytoplankton and zooplankton leads to a decrease in the TA value in the surface water layer. As these particles deposit and $\mathrm{pH}$ decreases, their dissolution occurs, which is accompanied by an increase in TA [20].

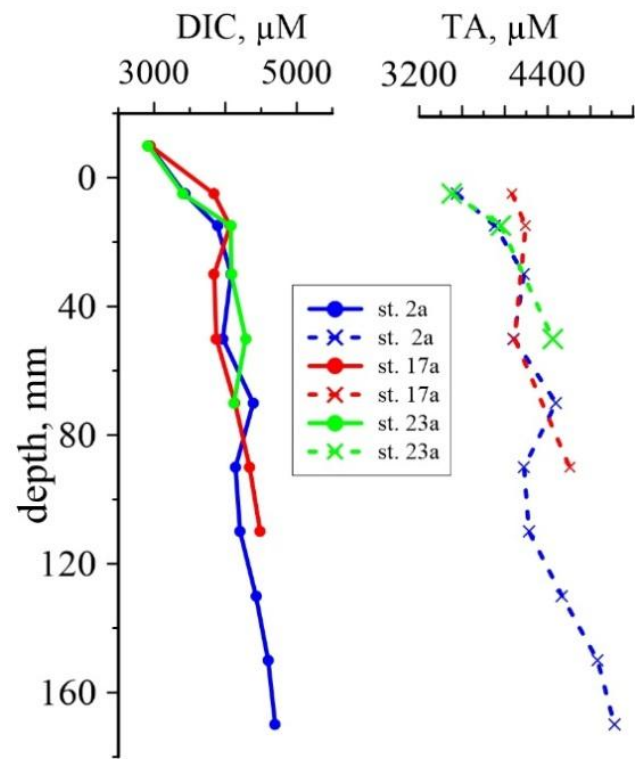

F i g. 2. Vertical profile of DIC, $\mu \mathrm{mol} \cdot \mathrm{kg}^{-1}$, and total alkalinity $(T A), \mu \mathrm{mol} \cdot \mathrm{l}^{-1}$

The change in DIC and TA in the pore waters of bottom sediments largely depends on the biogeochemical transformation of organic matter and on geochemical processes involving calcium carbonate. If DIC change is associated with the microbiological processes of organic carbon oxidation, the change in TA is the result of dissolution of calcium carbonate in the interaction with $\mathrm{CO}_{2}$ resulting from the oxidation of organic carbon, or the anaerobic oxidation of organic carbon, leading to the formation of sulfides. Taking into account high 
content of organic matter in the bottom sediments of the Sevastopol Bay (more than $4 \%$ dry weight), its transformation in the bottom sediments leads to significant changes in the components of the carbonate system in the pore waters compared to the bottom waters.

Taking into account the fact that organic matter microbiological oxidation can be carried out using different electron acceptors, depending on the external environmental conditions, different ratios in the increments of TA and DIC are observed. In particular, for $\mathrm{O}_{2}, \mathrm{SO}_{4}^{2-}$ acceptors, according to the stoichiometric equations of aerobic

$$
\left(\mathrm{CH}_{2} \mathrm{O}\right)_{106}\left(\mathrm{NH}_{3}\right)_{16}\left(\mathrm{H}_{3} \mathrm{PO}_{4}\right)+106 \mathrm{O}_{2} \leftrightarrow 106 \mathrm{CO}_{2}+16 \mathrm{HNO}_{3}+\mathrm{H}_{3} \mathrm{PO}_{4}+122 \mathrm{H}_{2} \mathrm{O}
$$

and anaerobic

$$
\left(\mathrm{CH}_{2} \mathrm{O}\right)_{106}\left(\mathrm{NH}_{3}\right)_{16}\left(\mathrm{H}_{3} \mathrm{PO}_{4}\right)+53 \mathrm{SO}_{4}^{2-} \rightarrow 106 \mathrm{HCO}_{3}^{-}+53 \mathrm{H}_{2} \mathrm{~S}+16 \mathrm{NH}_{3}+\mathrm{H}_{3} \mathrm{PO}_{4}
$$

Oxidation of organic matter, $\triangle \mathrm{TA} / \Delta \mathrm{DIC}$ relation will be equal to -0.16 and 1.14 , respectively. When calcium carbonate (magnesium) is dissolved in bottom sediments, $\Delta \mathrm{TA} / \Delta \mathrm{DIC}$ ratio is $2[21]$ in accordance with the equation

$$
\mathrm{CaCO}_{3}+\mathrm{CO}_{2}+\mathrm{H}_{2} \mathrm{O} \rightarrow \mathrm{Ca}^{2+}+2 \mathrm{HCO}_{3}^{-} .
$$

In the bottom sediments of the Sevastopol Bay, parallel DIC and TA growth with depth is observed (Fig. 2). By the character of their distribution, we can assume the anaerobic nature of organic matter transformation in accordance with the equation (2). In this case, it is obvious that $\mathrm{HCO}_{3}^{-}$and $\mathrm{CO}_{2}$ are the main products of organic carbon oxidation. In addition, $\triangle \mathrm{TA} / \triangle \mathrm{DIC}$ is close to 1.14 value of (Fig. 3), from which it can be concluded that organic matter oxidation is accompanied by sulfate reduction. This is also confirmed by our earlier studies [22].

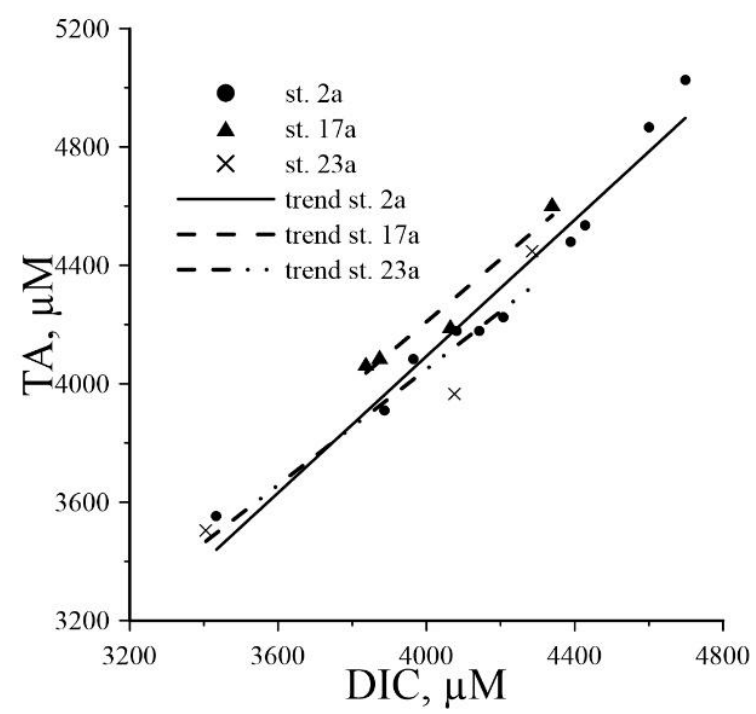

F i g. 3. Total alkalinity $(T A)$ and dissolved inorganic carbon (DIC) ratio in the Sevastopol Bay sediments. 
The obtained high-resolution vertical profiles of the components of bottom sediment pore waters carbonate system provided the calculation of DIC flux at the water - bottom sediments interface boundary. For this, the data from DIC direct measurements in the bottom waters and into the bottom sediments $(5,15,30$, $50 \mathrm{~mm}$ ), obtained in 2018 in various areas of the bay (st. 2a, 17a, 23a) were used (see Fig. 1) with different levels of anthropogenic load. To eliminate the effect of advection and turbulent diffusion processes in the water column, an approach for estimating the magnitudes of fluxes from the bottom sediments, taking into account the continuity principle [22], was used.

DIC flux was calculated taking into account molecular diffusion of dissolved compounds and the concentration gradient according to the first Fick's law [23]

$$
J=-\varphi D_{\mathrm{s}} d C / d Z,
$$

where $J$ is a flux, $\mathrm{mol} \cdot \mathrm{year}^{-1} \cdot \mathrm{m}^{-2}$; $\varphi$ is porosity; $d C / d Z$ is concentration gradient, $\mathrm{mol} \cdot\left(\mathrm{m}^{-3} \cdot \mathrm{m}^{-1} ; D_{\mathrm{s}}\right.$ is a molecular diffusion coefficient with regard to viscosity, $\mathrm{m}^{2} \cdot$ year $^{-1}$.

$$
D_{\mathrm{s}}=D_{0} / \theta^{2},
$$

where $D_{0}$ is water molecular diffusion coefficient, $\mathrm{m}^{2} \cdot$ year $^{-1} ; \theta$ is viscosity.

DIC diffusion coefficient for water column were taken from [24] with regard to temperature correction. The molecular diffusion coefficient of pore waters of bottom sediments with allowance for viscosity is calculated by the equation

$$
\theta^{2}=1-\ln \left(\varphi^{2}\right)
$$

Since the main contribution to DIC is made by $\mathrm{HCO}_{3}^{-}$ions (about $87 \%$ [16]), the values of $D_{\mathrm{s}}\left(\mathrm{HCO}_{3}^{-}\right)$were used for all calculations. The calculated values of the diffusion coefficients varied from $915 \cdot 10^{-6} \mathrm{~m}^{2} \cdot \mathrm{s}^{-1}$ at a temperature of $18{ }^{\circ} \mathrm{C}$ to $966 \cdot 10^{-6} \mathrm{~m}^{2} \cdot \mathrm{s}^{-1}$ at a temperature of $20^{\circ} \mathrm{C}$.

As one would expect, DIC flux is directed from bottom sediments to the bottom layer of water, therefore bottom sediments of the Sevastopol bay serve as a source of dissolved inorganic carbon for the water column. The average value of DIC flux is $-0.53 \mathrm{~mol} \cdot \mathrm{year}^{-1} \cdot \mathrm{m}^{-2}$. Taking into account the obtained value of the DIC flow and the area of the bay, the contribution of bottom sediments to the total budget of inorganic carbon is $48 \mathrm{t} \cdot$ year $^{-1}$.

It was revealed that in the summer period the parameters of carbonate system of the Sevastopol Bay waters are determined mainly by chemical and biological processes of photosynthesis and organic matter oxidation, in winter by the flood runoff of the Chernaya River (December - April) and hydrophysical processes of water exchange [10,19]. Over the past 10 years, a trend towards an increase in DIC, $p \mathrm{CO}_{2}$, and TA values and a decrease in $\mathrm{pH}$ has been observed in the bay ecosystem [19].

According to the results of multi-year of research, it was concluded that the anthropogenic component predominantly affects the hydrochemical regime of the bay. This is manifested in elevated (compared with the background values of the open part) concentrations of nutrients approaching the MPC or even exceeding it, as well as in the growth trend of the concentrations of almost all nutrients, DIC 
and $p \mathrm{CO}_{2}$ in the bay water area by 2016. A variation of $p \mathrm{CO}_{2}$ value (by more than $30 \%$ ) indicates a change in the ratio of the carbonate system components [19].

According to multi-year research, it was determined that the content of total dissolved inorganic carbon (DIC) in the bay waters is $3026 \mu \mathrm{mol} \cdot \mathrm{kg}^{-1}$. Taking into account the morphometric characteristics of the bay, (total area of the bay is $7.50 \cdot 106 \mathrm{~m}^{2}$, average depth is $12.5 \mathrm{~m} *$ ) total content of inorganic carbon is $\sim 3400 \mathrm{t}$.

The Chernaya River runoff serves as an additional source of nutrients and inorganic carbon for the Sevastopol Bay waters. In order to assess the river contribution to the water and salt balance of the Sevastopol Bay, the data on longterm runoff of the Chernaya River and nutrients concentration and components of the carbonate system for the mainstream section (Khmelnitsky gauging station) were studied. It was determined that average concentrations of nutrients in waters entering the bay with river runoff are higher than in the seawater (4-6 times), with the exception of phosphates. Their concentration in the river is 10 times higher [25].

The Chernaya River waters are also one of the main sources of bicarbonates for the Sevastopol Bay. According to the long-term monitoring (2007-2017) of the Chernaya River hydrological and hydrochemical characteristics, the average content of total dissolved inorganic carbon in the Khmelnytsky gauging station is $3488 \mu \mathrm{mol} \cdot \mathrm{kg}^{-1}$. Thus, the contribution of river flux $\left(57.1 \cdot 10^{6} \mathrm{~m}^{3} \cdot \mathrm{year}^{-1}\right.$ [9]) to the total budget of inorganic carbon in the waters of the Sevastopol Bay is $310 \mathrm{t} \cdot \mathrm{year}^{-1}$ according to the equation

$$
R_{\text {Cinorg }}=\Delta C_{\mathrm{cp}} \cdot W_{\mathrm{c}},
$$

where $R_{\text {Cinorg }}$ is an intake of dissolved inorganic carbon with the Chernaya River waters; $\Delta C_{\mathrm{cp}}$ is the difference between the Chernaya River DIC and DIC of the Sevastopol Bay waters, $\mu \mathrm{mol} \cdot \mathrm{kg}^{-1} ; W_{\mathrm{c}}$ is an annual average discharge of the Chernaya River waters.

In order to estimate the fluxes between the waters of the bay and the adjacent part of the sea, the water exchange in the bay exit area was $100 \mathrm{~m}^{3} \cdot \mathrm{s}^{-1}$ [26]. The difference between the DIC of the waters of the bay and DIC of the open sea is $39 \mu \mathrm{mol} \cdot \mathrm{kg}^{-1}$; therefore, every year 1476 tons of inorganic carbon are removed from the bay into the sea.

According to the averaged data for 2009-2018 on the carbon dioxide flux, equal to $6.85 \mathrm{~mol} \cdot \mathrm{day}^{-1} \cdot \mathrm{m}^{-2}$, and the data on the inorganic carbon input with the atmospheric precipitation, the atmospheric contribution to the total balance of inorganic carbon in the Sevastopol Bay waters was calculated. In order to calculate the contribution of atmospheric precipitation, it was assumed that their volume getting into the bay waters is $2.75 \cdot 10^{6} \mathrm{~m}^{3} \cdot$ year $^{-1}$ (according to long-term observations of Sevastopol Marine Hydrometeorological Station), and the concentration of dissolved inorganic carbon is determined by carbon dioxide $\left(p \mathrm{CO}_{2}\right)$ partial pressure in atmosphere, which is equal to $410 \mu \mathrm{atm}$. Other forms of inorganic carbon were not taken into account in atmospheric precipitation. Under these assumptions, not less than $16 \mathrm{t} \cdot \mathrm{year}^{-1}$ of inorganic carbon get into the bay waters.

\footnotetext{
* Water resources of Sevastopol. Surface waters. Available at: http://ecosev.ru/deyatelnost/vodnye-resursy/340-obshchie-svedeniya [Accessed: 01 November 2018] (in Russian).
} 


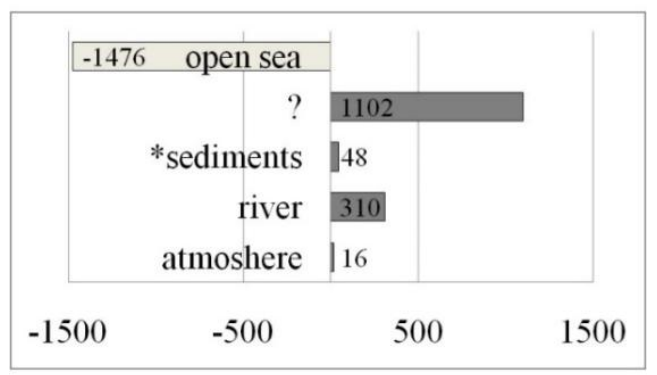

F i g. 4. Budget of dissolved inorganic carbon in the Sevastopol Bay ecosystem, $t \cdot y^{-1} r^{-1}$

Thus, the sum of the contribution of sources known to us is $374 \mathrm{t} \cdot \mathrm{year}^{-1}$. Taking into account the fact that up to $1476 \mathrm{t}$ of inorganic carbon are carried annually from the bay to the open sea, the difference in $1102 \mathrm{t} \cdot \mathrm{year}^{-1}$ is probably the contribution of anthropogenic sources. A conceptual budget model of inorganic carbon can be proposed in the form of a scheme (Fig. 4).

\section{Conclusions}

The results of the bottom sediment carbonate system study: vertical profile of total dissolved inorganic carbon, alkalinity and $\mathrm{pH}$, as well as the ratio between dissolved inorganic carbon and alkalinity, showed that the oxidation of organic matter occurs mainly under anaerobic conditions.

The obtained values of the total dissolved inorganic carbon flux $\left(J_{\text {DIC }}\right)$ at the "water - bottom sediments" boundary slightly vary over the bay area, the flux is directed from the bottom sediments to the bottom water layer and is $=0.42 \ldots 0.61 \mathrm{~mol} \cdot \mathrm{year}^{-1} \cdot \mathrm{m}^{-2}$.

DIC fluxes from the bottom sediments to the bottom water layer obtained for the first time provided the estimation of their contribution to the total inorganic carbon budget of the Sevastopol Bay.

As a result of analysis of various components of the inorganic carbon budget, it was determined that the greatest contribution is made by anthropogenic sources: carbon gets from household and industrial wastewaters, with terrigenous organic and inorganic matter, nutrients, washes off with fertilizers. Even if we take the current inorganic carbon intake with the river runoff as a natural component of the Sevastopol Bay inorganic carbon budget, the contribution of anthropogenic sources is at least $75 \%$ of the total inorganic carbon intake. At the same time, according to the total stock of dissolved inorganic carbon (about 3400 tons) and removal to the open sea (1476 t.year ${ }^{-1}$ ), it can be assumed that the time for complete renewal of the Sevastopol Bay waters is 2 years 4 months. A similar ratio of dissolved inorganic carbon stock to its intake with river waters, even taking into account the anthropogenic components of contemporary river waters, is almost 11 years.

Thus, the Sevastopol Bay ecosystem is formed mainly under effect of anthropogenic factors, the contribution of which is many times greater than the effect of natural factors. Only rather intensive water exchange between the bay and the adjacent sea to some extent balances the effect of anthropogenic sources and ensures the functioning of the bay ecosystem in a relatively acceptable condition. 


\section{REFERENCES}

1. Schmidtko, S., Stramma, L. and Visbeck, M., 2017. Decline in Global Oceanic Oxygen Content during the Past Five Decades. Nature, [e-journal] 542(7641), pp. 335-339. https://doi.org/10.1038/nature21399

2. Breitburg, D., Levin, L.A., Oschlies, A., Grégoire, M., Chavez, F.P., Conley, D.J., Garçon, V., Gilbert, D. and Gutiérrez, D. [et al.], 2018. Declining Oxygen in the Global and Coastal Waters. Science, [e-journal] 359(6371), eaam 7240. doi:10.1126/science.aam7240

3. Dore, J.E., Lukas, R., Sadler, D.W., Church, M.J. and Karl, D.M., 2009. Physical and Biogeochemical Modulation of Ocean Acidification in the Central North Pacific. Proceedings of the National Academy of Sciences of the United States of America, [e-journal] 106(30), pp. 12235-12240. https://doi.org/10.1073/pnas.0906044106

4. Cai, W.-J., Hu, X., Huang, W.-J., Murrell, M.C., Lehrter, J.C., Lohrenz, S.E., Chou, W.-C., Zhai, W., Hollibaugh, J.T. [et al.], 2011. Acidification of Subsurface Coastal Waters Enhanced by Eutrophication. Nature Geoscience, [e-journal] 4(11), pp. 766-770. doi:10.1038/NGEO1297

5. Chen, C.-T.A., Huang, T.-H., Chen, Y.-C., Bai, Y., He, X. and Kang, Y., 2013. Air-Sea Exchanges of $\mathrm{CO}_{2}$ in the World's Coastal Seas. Biogeosciences, [e-journal] 10(10), pp. 65096544. https://doi.org/10.5194/bg-10-6509-2013

6. Wang, Z.A., Wanninkhof, R., Cai, W.-J., Byrne, R.H., Hu, X., Peng, T.-H. and Huang, W.-J., 2013. The Marine Inorganic Carbon System Along the Gulf of Mexico and Atlantic Coasts of the United States: Insights from a Transregional Coastal Carbon Study. Limnology and Oceanography, [e-journal] 58(1), pp. 325-342. https://doi.org/10.4319/lo.2013.58.1.0325

7. Bauer, J.E., Cai, W.-J., Raymond, P.A., Bianchi, T.S., Hopkinson, C.S. and Regnier, P.A.G., 2013. The Changing Carbon Cycle of the Coastal Ocean. Nature, [e-journal] 504(7478), pp. 61-70. doi:10.1038/nature 12857

8. Ovsyany, E.A., Artemenko, V.M., Romanov, A.S. and Orekhova, N.A., 2007. Stok Reki Chernoy kak Faktor Formirovaniya Vodno-Solevogo Rezhima i Ekologicheskogo Sostoyaniya Sevastopol'skoy Bukhty [The Chernaya River Discharge as a Factor Affecting the Water-Salt Regime Forming and Ecological State of the Sevastopol Bay]. In: MHI, 2007. Ekologicheskaya Bezopasnost' Pribrezhnykh i Shel'fovykh Zon i Kompleksnoe Ispol'zovanie Resursov Shel'fa [Ecological Safety of Coastal and Shelf Zones and Comprehensive Use of Shelf Resources]. Sevastopol: ECOSI-Gidrofizika. Iss. 15, pp. 57-65 (in Russian).

9. Ovsyany, E.I. and Orekhova, N.A., 2018. Hydrochemical Regime of the River Chernaya (Crimea): Environmental Aspects. Physical Oceanography, [e-journal] 25(1), pp. 77-88. doi: 10.22449/1573-160X-2018-1-77-88

10. Ivanov, V.A., Ovsyany, E.I., Repetin, L.N., Romanov, A.S. and Ignatyeva, O.G., 2006. Gidrologo-Gidrokhimicheskiy Rezhim Sevastopol'skoy Bukhty $i$ Ego Izmeneniya pod Vozdeystviem Klimaticheskikh i Antropogennykh Faktorov [Hydrological and Hydrochemical Regime of the Sebastopol Bay and its Changing under Influence of Climatic and Anthropogenic Factors]. Sevastopol: MHI NASU, 90 p. (Preprint). Available at: http://mhiras.ru/assets/files/gidrologo-gidrohimicheskij_rezhim_sevastopolskoj_buhty_2006.pdf

「Accessed: 19 April 20191 (in Russian).

11. Mikhaylov, V.N., 1997. Gidrologicheskie Protsessy v Ust'yakh Rek [Hydrological Processes in Estuaries]. Moscow: GEOS, 175 p. (in Russian).

12. Bordovskiy, O.K. and Chernyakova, A.M., eds., 1992. Sovremennye Metody Gidrokhimicheskikh Issledovaniy Okeana [Modern Methods of Ocean Hidrochemical Investigations.]. Moscow: IO RAS, 201 p. (in Russian).

13. Millero, F.J., 2007. The Marine Inorganic Carbon Cycle. Chemical Reviews, [e-journal] 107(2), pp. 308-341. doi:10.1021/cr0503557

14. Zeebe, R.E. and Wolf-Gladrow, D., 2001. CO, in Seawater: Equilibrium, Kinetics, Isotopes. Elsevier Oceanography Series, vol. 65. Amsterdam: Elsevier Science, 360 p.

15. Unesco, 1987. Thermodynamics of the Carbon Dioxide System in Seawater. Unesco Technical Papers in Marine Science, vol. 51. Paris: Unesco, pp. 3-21. Available at: http://www.jodc.go.jp/jodcweb/info/ioc_doc/UNESCO_tech/077668eb.pdf [Accessed: 13 September 2018].

16. Millero, F.J., 1996. Chemical Oceanography. Boca Raton: CRC Press, 469 p.

17. Khoruzhiy, D.S., 2010. Ispol'zovanie Pribornogo Kompleksa AS-C3 dlya Opredeleniya Partsial'nogo Davleniya Uglekislogo Gaza i Kontsentratsii Neorganicheskogo Ugleroda v Morskoy Vode [Usage of Device Complex AS-C3 for Detection of Carbon Dioxide Partial Pressure and Inorganic Carbon Concentration in Sea Environment]. In: MHI, 2010. Ekologicheskaya Bezopasnost' Pribrezhnykh i Shel'fovykh Zon i Kompleksnoe Ispol'zovanie Resursov Shel'fa [Ecological Safety of Coastal and Shelf Zones and Comprehensive Use of Shelf Resources]. Sevastopol: ECOSI-Gidrofizika. Iss. 23, pp. 260-272 (in Russian). 
18. Khoruzhii, D.S., Ovsyanyi, E.I. and Konovalov, S.K., 2011. Comparison of the Results of Determination of the Carbonate System and the Total Alkalinity of Seawater According to the Data Obtained by Using Different Analytic Methods. Physical Oceanography, [e-journal] 21(3), pp. 182-194. https://doi.org/10.1007/s11110-011-9114-6

19. Orekhova, N.A. and Varenik, A.V., 2018. Current Hydrochemical Regime of the Sevastopol Bay. Physical Oceanography, [e-journal] 25(2), pp. 124-135. doi:10.22449/1573-160X-20182-124-135

20. Sabine, C.L., Key, R.M., Feely, R.A. and Greeley, D., 2002. Inorganic Carbon in the Indian Ocean: Distribution and Dissolution Processes. Global Biogeochemical Cycles, [e-journal] 16(4). 1067. https://doi.org/10.1029/2002GB001869

21. Cai, W.-J., Huang, W.-J., Luther III, G.W., Pierrot, D., Li, M., Testa, J., Xue, M., Joesoef, A., Mann, R. [et al], 2017. Redox Reactions and Weak Buffering Capacity Lead to Acidification in the Chesapeake Bay. Nature Communications, [e-journal] 8. Article 369. https://doi.org/10.1038/s41467-017-00417-7

22. Orekhova, N.A. and Konovalov, S.K., 2018. Oxygen and Sulfides in Bottom Sediments of the Coastal Sevastopol Region of Crimea. Oceanology, [e-journal] 58(5), pp. 679-688. https://doi.org/10.1134/S0001437018050107

23. Hyacinthe, C., Anschutz, P., Carbonel, P., Jouanneau, J.-M. and Jorissen, F.J., 2001. Early Diagenetic Processes in the Muddy Sediments of the Bay of Biscay. Marine Geology, [e-journal] 177(1-2), pp. 111-128. https://doi.org/10.1016/S0025-3227(01)00127-X

24. Zeebe, R.E., 2011. On the Molecular Diffusion Coefficients of Dissolved $\mathrm{CO}_{2}, \mathrm{HCO}_{3}^{-}$and $\mathrm{CO}_{3}^{2-}$ and their Dependence on Isotopic Mass. Geochimica et Cosmochimica Acta, [e-journal] 75(9), pp. 2483-2498. https://doi.org/10.1016/j.gca.2011.02.010

25. Orekhova, N.A., Medvedev, E.V. and Ovsyany, E.I., 2018. Vliyanie Vod Reki Chernoy na Gidrokhimicheskiy Rezhim Sevastopol'skoy Bukhty (Chernoe More) [Influence of the River Chernaya Water on Hydrochemical Regime of the Sevastopol Bay (the Black Sea)]. In: MHI, 2018. Ekologicheskaya Bezopasnost' Pribrezhnoy i Shel'fovoy Zon Morya [Ecological Safety of Coastal and Shelf Zones of Sea]. Sevastopol: ECOSI-Gidrofizika. Iss. 3, pp. 84-91. doi:10.22449/2413-5577-2018-3-84-91 (in Russian).

26. Morozov, A.N., Lemeshko, E.M., Shutov, S.A., Zima, V.V. and Chepyzhenko, A.A., 2014. Techeniya v Sevastopol'skoy bukhte po dannym ADCP-nablyudeniy, noyabr' $2014 \mathrm{~g}$. [Currents in the Sevastopol Bay according to the data of ADCP observations, November 2014]. In: MHI, 2014. Ekologicheskaya Bezopasnost' Pribrezhnykh i Shel'fovykh Zon I Kompleksnoe Ispol'zovanie Resursov Shel'fa [Ecological Safety of Coastal and Shelf Zones and Comprehensive Use of Shelf Resources]. Sevastopol: ECOSI-Gidrofizika. Iss. 28, pp. 2530 (in Russian).

About the authors:

Natalia A. Orekhova - Head of Marine Biogeochemistry Department, Marine Hydrophysical Institute of RAS (2, Kapitanskaya Str., Sevastopol, 299011, Russian Federation), Ph.D. (Geogr.), SPIN-code: 9050-4772, ORCID ID: 0000-0002-1387-970X, ResearcherID: I-1755-2017, natalia.orekhova@mhi-ras.ru

Sergey K. Konovalov - Director, Marine Hydrophysical Institute of RAS (2, Kapitanskaya Str., Sevastopol, 299011, Russian Federation), corresponding member of RAS, Dr.Sci. (Geogr.), ORCID ID: 0000-0002-5200- 8448; director@mhi-ras.ru

Eugene V. Medvedev - Junior Research Associate, Marine Hydrophysical Institute of RAS (2, Kapitanskaya Str., Sevastopol, 299011, Russian Federation), ORCID ID: 0000-0002-6093-5102

Contribution of the co-authors:

Natalia A. Orekhova - formulation of the aims and objectives of the study; the literature review; interpretation of the results; preparation of graphic and text materials; correction of the paper.

Sergey K. Konovalov - general scientific research supervision; development and scientific substantiation of the concept; correction of the paper.

Eugene V. Medvedev - data preparation; preparation of graphic and text materials; processing and description of the research results.

All the authors have read and approved the final manuscript.

The authors declare that they have no conflict of interest. 